\title{
STRATEGI PENATAAN PERABOTAN RUMAH KOST DI DESA KARANG MALANG YOGYAKARTA
}

\author{
Tri Yuni Iswati ${ }^{1}$ dan Dyah.S.Pradnya.P 2 \\ Prodi Arsitektur,Fakultas Teknik, UNS \\ Prodi Arsitektur,Fakultas Teknik, UNS \\ Email : dyah pradnya@yahoo.com
}

\begin{abstract}
ABSTRAK
Desa Karang Malang merupakan salah satu lokasi kost di Yogyakarta. Penyewa rumah kost terdiri dari mahasiswa, pegawai dan pedagang. Rumah kost di desa tersebut ada 3 jenis, yaitu : rumah kost putra, rumah kost putri dan rumah kost putra-putri. Sedangkan lokasi rumah kost terdapat 2 jenis pula, yaitu : kamar kost yang terpisah dari rumah pemilik kost dan rumah kost yang sekaligus rumah pemilik kost. Ruang kost terlihat rapi dan longgar., namun perabotan pribadi berupa pakaian kotor, dan sepatu diletakkan di samping pintu ruang kost sehingga mengganggu sirkulasi dan suasana di ruang komunal. Berdasarkan fenomena, tim peneliti tertarik untuk mengeksplorasi faktor-faktor penyebab dan memberikan solusi. Metode Naturalistik Kualitatif yang digunakan dalam penelitian ini memiliki unit ekplorasi dan analisis data berupa 11 rumah kost. Teknik pengumpulan dan analisis data menggunakan Purposive Sampling, Snowball Sampling dan sistem Cross Sectional. Hasil penelitian menunjukkan bahwa penyewa rumah kost cenderung mengutamakan kepentingan pribadi, kepedulian terhadap psikologi lingkungan lemah, serta memanfaatkan setiap ruang untuk meletakkan perabotan pribadi.
\end{abstract}

Kata-kata kunci : rumah kost, ruang, perabotan bersama, penyewa, pribadi

ABSTRACT

Karang Malang village is one of locations boarding in Yogyakarta. A tenant of the boarding house consisting of the students, employees and traders. Boarding house in the village, there are three types namely: the boarding house of male, the boarding house of female, and the boarding house of both. The location of boarding house there are two types of all, namely: the boarding house separate from the owner of boarding and boarding house who was also the owner of lodging house. The boarding room looks neat and loose. Furnishing, but dirty clothes, private in the form of and shoes always put beside the boarding room.. The existence of the personal belongings of course interrupting the circulation and the atmosphere of communal activities performed in space. Based on this phenomenon the researchers team interested to explored factors caused and provided solutions. This research was done using Naturalistic Qualitative method for 6 months. Sampling was used as the unit of exploration and the analysis consisted of 11 boarding house. For observation, the researcher always explored every data and took information from some sources. The researcher collected data using Purposive Sampling technique, Snowball Sampling technique dan Cross Sectional system. The results of the study showed that renters tended to give priority to home kost personal interests, concern for the pshychology of environment looks weak giving rise to disturbances in the various parties as well as take advantage of any space to put personal furniture.

Key words : boarding house, space, communal furnishing, tenants, personal 


\section{Pendahuluan}

Desa Karang Malang merupakan salah satu lokasi pedesaan, di sebelah Utara Yogyakarta. Posisi pemukiman desa tersebut strategis, sehingga dimanfaatkan untuk usaha rumah-rumah kost mahasiswa . Tarip sewa rumah kost bervariasi, tergantung fasilitas yang disediakan oleh setiap rumah kost. Motivasi membangun rumah kost adalah kebutuhan ekonomi dan untuk mencari teman. Dari uang sewa tersebut, setiap tahun pemilik rumah kost dapat membangun 1 kamar kost. Mengenai sistem pengelolaan sewa, pemilik rumah kost dapat menangani secara langsung atau dititipkan kepada kaum kerabat yang tinggal di lokasi rumah kost. Adapun jenis rumah kost di desa Karang Malang, ada 3 macam, yaitu :

1. Kost Putra

2. Kost Putri

3. Kost Putra -Putri yang terdiri atas 2 jenis, yaitu :

a.Satu lokasi yaitu terdapat beberapa rumah untuk kost Putra dan kost Putri

b.Satu rumah yaitu satu rumah dengan banyak kamar untuk kost Putra dan kost Putri

Sedangkan status kepemilikkan rumah kost, terdapat 2 golongan kepemilikan, yaitu pribumi dan pendatang.

Penyewa rumah kost kebanyakan mahasiswa S1 Universitas Gajah Mada dan Universitas Negeri Yogyakarta yang masih bujangan. Dalam kegiatan sosial kampung, penyewa kamar kost berinteraksi dengan tetangga kost, penduduk dan tamu. Aktivitas tersebut berupa pengajian, pernikahan, kematian, organisasi. Fenomena yang menarik serta sering ditemui di rumah-rumah kost di Desa Karang Malang adalah peletakkan pakaian kotor dan sepatu di ruang komunal (ruang bersama dan ruang tamu). Penyewa tidak khawatir kehilangan pakaian kotor dan sepatu, sedangkan keluarga pemilik rumah kost juga tidak risih dengan keberadaan pakaian kotor dan sepatu tersebut. Sementara kamar kost terlihat longgar dan rapi serta menempati zona paling besar bila dibandingkan dengan zone rumah induk. Kondisi tersebut menimbulkan kontradiksi situasi, sehingga memicu keengganan para penyewa kamar kost untuk melakukan berbagai aktivitas di ruang komunal. Mayoritas aktivitas dilakukan di dalam kamar



Gambar 1. Desa Karang Malang Yogyakarta

Sumber: Pendataan Kelompok Penelitian S2 Teknik Arsitektur UGM, 2003 




Gambar 2. Letak rumah-rumah kost di Desa Karang Malang Yogyakarta Sumber : Pendataan Kelompok Penelitian S2 Teknik Arsitektur UGM, 2003

Permasalah yang hendak dijawab dalam penelitian ini adalah: Faktor-faktor apa saja yang melatar belakangi penataan perabotan rumah kost? Manfaat penelitian ini adalah agar keberadaan penataan perabotan dalam kamar kost dapat difungsikan secara seimbang untuk aktivitas personal maupun komunal.

\section{Bahan dan Metode}

\subsection{Rumah}

Rumah merupakan tempat untuk beraktivitas yang mencerminkan kepribadian pemilik rumah. Seperti penjelasan Heidegger dalam Schultz (1971), bahwa :

"Dwelling is the basic principle of existence".

Lalu Gaston Bachelard dalam Schultz (1971), juga menjelaskan bahwa:

The house as "one of the great integrative forces in man's life

Bachelard dalam Schultz (1971), menambahkan pula, bahwa :

- The image of the house, therefore, depends on the existence of differentiated places which interact among themselves and with the environment in variying ways

- The character is determined by concrete 'things' such as the fire place, the table and the bed

Kemudian Schultz ( 1971 ) mendukung penjelasan Bachelard, bahwa :

The essence of the house as architecture, therefore, is interior space. In the city, we are still outside, although we have left the open landscape. In the house we are alone with ourselves, we have withdrawn 


\subsection{Ruang}

Areal nyata selalu dibatasi oleh teritorial fisik sedangkan areal abstrak selalu dibatasi oleh teritorial non fisik. Seperti pernyataan dari Tuan ( 1977 ), bahwa :

Ruang adalah zone abstrak yang mengalami perubahan serta tidak dibatasi oleh dinding, partisi maupun bentuk pembatas . Misal: ruang dalam dunia anak, dimengerti sebagai wilayah bermain. Sedangkan tempat, berada pada posisi yang lebih terbatas dan bersifat tetap. Misal : tempat dalam dunia geologi diartikan sebagai daerah sumber minyak bumi, batu bara

Sedangkan Tzu ( 550 SM ) dalam Van Nostrand Reinhold menekankan pada batas antara ruang internal dan eksternal yaitu dinding pemisah. Di samping itu, juga menyimpulkan bahwa terdapat 3 tahapan dalam hirarki ruang, yaitu :

- Ruang sebagai hasil dari perangkaian secara tektonik



Gambar 3.Bentuk tektonik

Sumber : Ruang dalam Arsitektur (Van de Ven, 1995)

- Ruang yang dilingkupi bentuk stereotomik



Gambar 4.Bentuk stereotomik

Sumber : Ruang dalam Arsitektur (Van de Ven, 1995)

- $\quad$ Ruang peralihan yang membentuk suatu hubungan antara dunia

Di dalam dengan dunia di luar



Gambar 5.Bentuk perpindahan

Sumber : Ruang dalam Arsitektur ( Van de Ven, 1995)

Kemudian mengenai hubungan ruang, dibahas pula oleh Ching ( 1991 ). Hubungan ruang terbagi menjadi 4 pola, yaitu : 


\begin{tabular}{||c|c||}
\hline Ruang di dalam ruang & \\
\hline Ruang-ruang yang saling berkaitan & \\
\hline Ruang-ruang yang bersebelahan & \\
\hline $\begin{array}{l}\text { Ruang-ruang dihubungkan } \\
\text { oleh sebuah ruang bersama }\end{array}$ & \\
\hline
\end{tabular}

Gambar 6. Hubungan Ruang

Sumber : Bentuk Ruang dan Susunannya (DK.Ching, 1991)

\subsection{Teritorial}

Teritorial berfungsi sebagai areal pembatas / perpindahan antar kegiatan. Seperti penjelasan Pastalan (1970) dalam Lang, bahwa :

A territory is a delimited space that a person or a group uses and defens as an exclusive preserve. It involves psychological identification with a place, symbolized by attitudes of possessiveness and arrangements of objects in the area

Lalu Altman's ( 1975 ) dalam Lang memberikan definisi pula, sebagai berikut:

Territorial behavior is a self-other boundary regulation mechanism that involves personalization of or marking a place or object and communication that it owned by a person or group

Pendapat tersebut, dapat pula diartikan secara lebih terperinci sebagai berikut:

1.The ownership of or rights to a place

2.The personalization or marking of an area

3.The right to defend against intrusions

4.The serving of several function ranging from the meeting of basic

physiological needs to the satisfaction of cognitive and aesthetic needs

Altman ( 1975 ) dalam Lang mengatakan sisi lain tentang teritori, yaitu :

Territories not only as a means of attaining privacy but also as a means of stabilizing social relationship

Porteous ( 1977 ) dalam Lang menjelaskan secara terperinci, bahwa:

1.Personal space, control and personalize space and behavior

2.Home base, those spaces that are defended actively wheter they are work or residential or simply neighborhood areas

3.Home range, the behavior setting that form part of a person's life

Di sisi lain, Cooper ( 1974 ) dalam Lang mengatakan pula, bahwa :

The house is divided into two components : an intimate interior an public

exterior 'or the self as viewed from within and the self we choose to display to others

Kemudian Cappon ( 1970 ) dalam Lang memperkuat pendapat Cooper, bahwa : 
Extroverts like contact with environment, introverts prefer courtyard houses, misanthropes prefer buildings with complex internal relationship and clear territorial patterns, and mixers like strong central-plan hoses

\subsection{Perilaku}

Perilaku merupakan suatu kesimpulan dari kegiatan yang dilakukan secara rutin, dalam jangka waktu yang lama serta mencerminkan makna yang terkandung dibalik aktivitas. Seperti yang dijelaskan Rappaport ( 1979) dalam Bell ( 1992 ) bahwa :

Symbolic and utilitarian activities can be differentiated only in terms of the degree to which they are expressive or communicative and ritual, therefore, as the symbolic and expressive, constitutes some dimension of all social activity

\subsection{Metode Penelitian}

Penelitian dilakukan dengan metode Naturalistik Kualitatif selama 6 bulan. Sampel yang dipergunakan sebagai unit ekplorasi dan analisis data terdiri dari 11 rumah kost. Adapun teknik pengumpulan dan analisis data dipergunakan teknik Purposive Sampling, teknik Snowball Sampling dan sistem Cross Sectional

\section{Hasil dan Pembahasan}

\subsection{Tema 1 : Zone Personal}

Penyewa kamar kost, melakukan aktivitas pribadi pada 2 ruang yaitu kamar kost dan kamar mandi/WC. Aktivitas tersebut membutuhkan ruang yang luas. Perabotan yang disediakan terdiri atas almari, tempat tidur tanpa kaki dan kasur. Keterbatasan luasan kamar kost, menstimulan penyewa untuk meletakkan perabotan pribadi berupa rak sepatu dan tempat pakaian kotor di luar kamar kost. Pintu kamar kost berhubungan langsung dengan ruang bersama atau ruang tamu sehingga terlihat kotor, padat, gelap,berbau serta menimbulkan suasana kurang nyaman. Di sisi lain, ruang jemuran justru dipergunakan sebagai zone personal dan zone komunal. Interaksi antar para penyewa kamar kost sering dilakukan di sini. Interaksi tersebut juga terjadi di tempat parkir motor rumah kost di dan dapur.

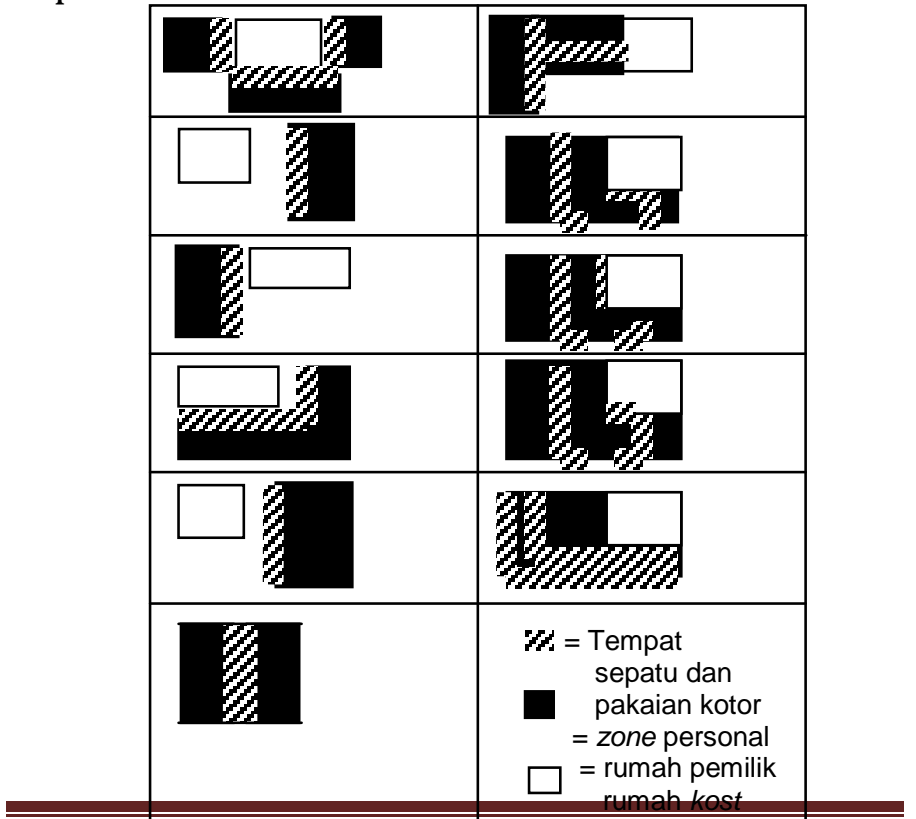

Gambar 7. Zone personal 


\section{Simpulan :}

Terjadi pergeseran fungsi antara ruang jemuran, ruang parkir dan dapur yang semula sebagai area servis, berubah menjadi tempat untuk berinteraksi. Para penyewa kamar kost terlihat lebih suka berinteraksi sambil melakukan aktivitas harian, sehingga keakraban antar para penyewa kamar kost terlihat natural. Di samping itu, tamu yang bertandang dan berbincang, juga akan dilayani dengan ramah dan terbuka. Ruang jemuran dan ruang parkir merupakan area service yang berada di ruang terbuka dan berhubungan langsung dengan halaman rumah kost. Sedangkan dapur merupakan area service yang berada di dalam rumah kost. Para penyewa cenderung menempatkan barang barang pribadi di ruang komunal tanpa khawatir hilang maupun rusak. Hal ini dilakukan untuk memberi kesan luas pada kamar kost. Sementara untuk ruang bersama dan ruang tamu ,justru terlihat kosong dari berbagai aktivitas. Karakteristik ruang bersama dan ruang tamu identik dengan kamar kost yaitu sebagai ruang personal.

\section{2 .Tema 2 :Keberadaan Tamu}

Setiap tamu yang baru dikenal diterima di ruang tamu oleh pemilik rumah kost. Bila perbincangan berkisar pada keberadaan rumah kost, maka suasana perkenalan sering kali terasa kaku, curiga, terbatas serta penuh ekspresi pertanyaan. Jam berkunjung bagi tamu, dibatasi sampai pukul 21.00. Namun bila tamu berkeinginan untuk menyewa kamar kost, maka pemilik rumah kost terlihat lebih terbuka dan lebih akrab. Di samping itu, bila tamu yang berkunjung adalah teman maupun keluarga dari para penyewa kamar kost, maka ruang yang dipergunakan untuk menerima tamu adalah kamar kost, dengan jam kunjung yang lebih leluasa. Dalam situasi ini, pemilik rumah kost menerima para tamu dengan terbuka dan leluasa. Untuk menerima tamu, diperlukan kamar kost yang luas dan nyaman sehingga para penyewa kamar kost pun sering kali memindahkan perabotan dari dalam kamar kost ke luar kamar kost. Hal ini diperjelas dalam gambar berikut :



Gambar 8. Zone Keberadaan Tamu

Sumber : Survey, 2010 


\section{Simpulan :}

Kamar kost menjadi tempat pemusatan aktivitas personal yang sangat tertutup. Hanya orang-orang yang memiliki hubungan tertentu dapat memasuki kamar kost. Dalam hal ini, teritorial kamar kost dibentuk atas 4 unsur, yaitu : tembok, tatapan mata, sepatu dan tempat pakaian kotor. Sedangkan posisi ruang bersama dan ruang tamu memperkuat ketertutupan tersebut. Penguatan fungsi kamar kost telah menjadikan area tersebut menjadi tempat yang khusus. Ruang komunal yang berupa ruang bersama dan ruang tamu dirasakan kurang nyaman, maka kamar kost menjadi tempat yang paling nyaman dan privat untuk menerima tamu. Dalam hal ini, peran tamu sangat kuat karena menentukan keterbukaan atau ketertutupan kamar kost. Selain tamu yang berkunjung untuk berbagai aktivitas, juga tamu yang menginap. Bila menginap, maka faktor yang memperkuat fungsi kamar kost adalah waktu.

\subsection{Tema 3 : Interaksi komunal}

Penyewa kamar kost berasal dari berbagai suku di Indonesia. Beragam budaya dan dialek dapat dirasakan saat terjadi interaksi pergaulan Sedangkan mengenai religi juga beragam yaitu Islam, Kristen dan Katolik. Namun dalam rumah kost, latar belakang budaya dan religi tersebut tidak menjadi faktor dominan. Para penyewa kamar kost cenderung lebih suka menyembunyikan identitas diri, sehingga interaksi terasa terbatas dan cenderung tertutup. Penyewa kamar kost cenderung berinteraksi personal dengan kelompok atau teman dekat. Ruang yang selalu dipergunakan dalam berinteraksi adalah kamar kost, sehingga terjadi penumpukan aktivitas di dalam kamar kost. Situasi tersebut menyebabkan para penyewa kamar kost memindahkan barang dan perabotan ke luar kamar. Ruang tamu dan ruang bersama terlihat kosong dari aktivitas, namun penuh dengan sepatu dan pakaian kotor. Walaupun para penyewa kamar kost kurang nyaman dengan heterogenitas tersebut, namun aktivitas kuliah maupun bekerja telah menyita waktu yang besar sehingga latar belakang budaya tidak menjadi faktor yang menentukan keakraban. Dari aspek religi , tidak terdapat perbedaan yang mencolok antar penganut agama. Namun justru masalah ke-sekuler-an agama yang cukup mencolok. Kebanyakan para penyewa kamar kost tidak terlalu tekun menjalankan ibadah. Hubungan komunal antar para penyewa kamar kost cukup akrab sehingga dapat menyatu dengan pemilik rumah kost serta warga di sekitar rumah kost. Hal ini akan diperlihatkan dalam gambar berikut

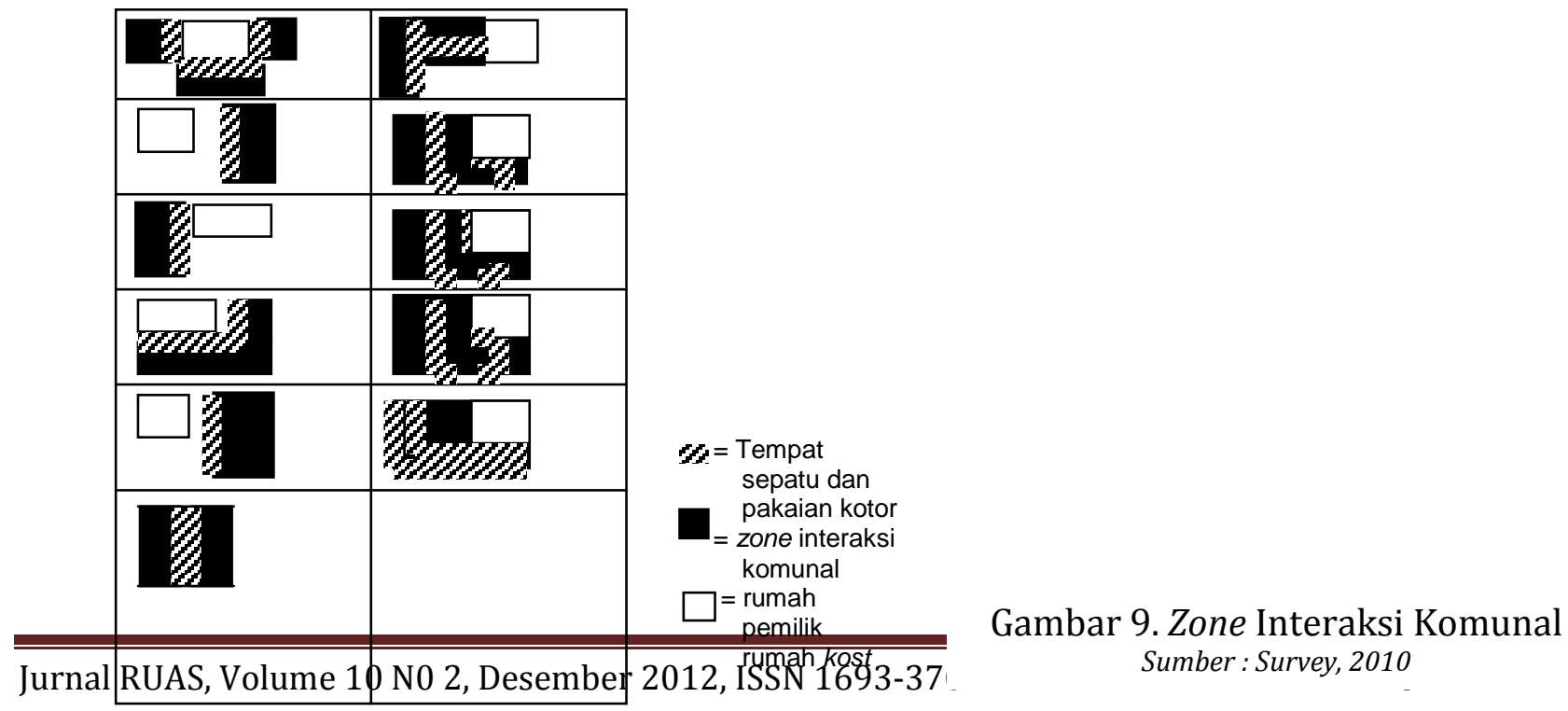




\section{Simpulan :}

Dalam komunitas sosial, para penyewa kamar kost memang terlihat akrab, namun jarang memperlihatkan identitas diri. Sehingga sifat pergaulan adalah sebatas pada kepentingan bersama pada saat terlibat dalam berbagai aktivitas. Para penyewa kamar kost sering kali merasa terganggu, bila ditanya mengenai identitas diri. Adapun yang mengetahui mengenai identitas diri para penyewa kamar kost adalah yang memiliki hubungan kekerabatan. Meskipun masalah budaya tidak timbul di antara para penyewa kamar kost, namun tingkat religi kebanyakan penyewa cukup memprihatinkan.Identitas religi dan budaya daerah juga kurang diekspresikan, sehingga mayoritas identitas setiap penyewa kamar kost sama. Adapun yang membedakan identitas terletak pada dialek pribadi . Sikap yang tertutup tersebut membawa pengaruh yang besar terhadap cara berpikir. Hal ini terlihat juga pada pengaturan kamar kost yang justru menunjukkan identitas diri yang tertutup. Jadi kamar kost adalah identitas diri dari para penyewa kamar kost.

\subsection{Tema 4 : Keberadaan pemilik rumah kost}

Kamar-kamar kost cenderung menempati zone yang terpisah dari pemilik rumah kost, sehingga kebebasan dan keleluasaan mendominasi aktivitas sehari-hari. Aktivitas interaksi dalam rumah kost, juga hanya dipahami oleh setiap penyewa kamar kost. Pemisahan zone dengan pemilik rumah kost telah menjadikan ruang tamu dan ruang bersama dimanfaatkan secara bebas dan maksimal oleh para penyewa kamar kost. Berbagai aktivitas dan penempatan barang menjadi kebiasaan sehari-hari. Pemilik rumah kost cenderung pula menempati luasan rumah yang minimal. Sehingga para penyewa kamar kost maupun pemilik rumah kost berada dalam kesibukan masing-masing. Sehingga untuk bertegur sapa ataupun berbincang pun jarang dilakukan. Walaupun berada dalam satu lokasi rumah kost, interaksi antara para penyewa kamar kost dan pemilik rumah kost jarang terjadi. Para pemilik rumah kost pun banyak yang sudah berusia renta, sakit dan tidak mampu mengawasi rumah kost. Hal ini akan diperlihatkan dalam gambar berkut :

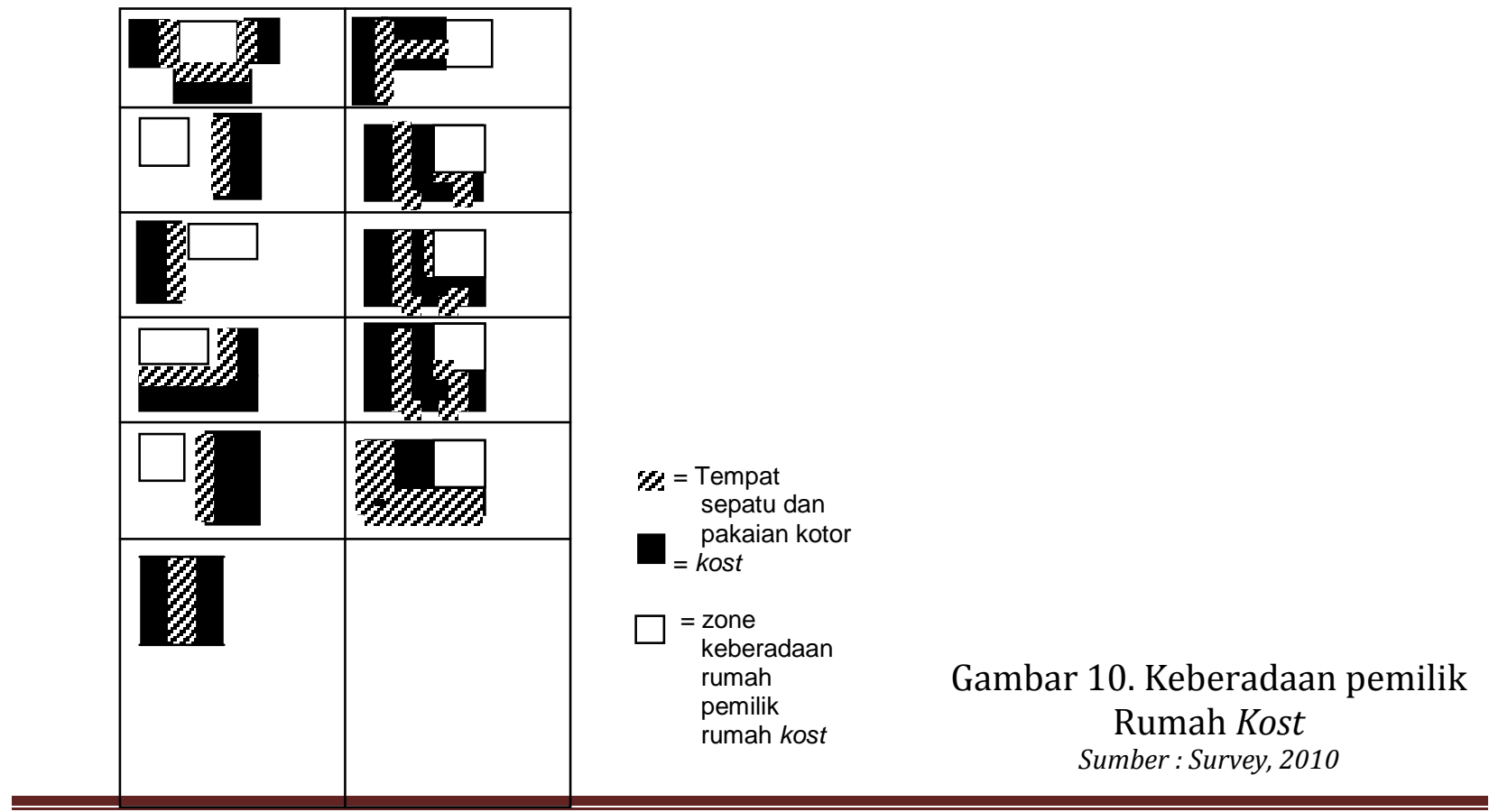

Jurnal RUAS, Volume 10 N0 2, Desember 2012, ISSN 1693-3702 


\section{Simpulan :}

Pemilik rumah kost lebih cenderung menjadi penjaga yang pasif. Peran para pemilik rumah kost cenderung minimal, karena keterbatasan tenaga, usia yang sudah tua dan tubuh yang renta. Sehingga dengan segala keterbatasan itu, mempengaruhi perilaku para penyewa kamar kost. Para penyewa kamar kost cenderung memanfaatkan keadaan tersebut untuk berbagai aktivitas. Mereka merasa bebas untuk mengatur kehidupan dan menata ruangan semaksimal mungkin. Kebebasan yang maksimal terlihat pada hampir seluruh penyewa kamar kost. Kebebasan itu tidak hanya terlihat pada kamar kost yang terpisah dari rumah induk, namun juga kamar kost yang menjadi satu dengan rumah induk.Dalam hal ini posisi para pemilik rumah kost sangat lemah, sehingga menimbulkan kebebasan yang berlebihan.

\section{Kesimpulan dan Saran}

\subsection{Simpulan Tema-tema}

- Penyewa rumah kost cenderung mengutamakan kepentingan pribadi

- Kepedulian terhadap psikologi lingkungan terlihat lemah sehingga menimbulkan gangguan di berbagai pihak

- Memanfaatkan setiap ruang untuk meletakkan perabotan pribadi.

\subsection{Saran}

- Diperlukan pembinaan etika dalam penyediaan fasilitas kamar kost

- Diperlukan pertimbangan antara keuntungan dan suasana batin yang dibangun

- Aturan harus dikomunikasikan secara lisan maupun tulisan

- Pemberian pujian dan teguran bagi yang melanggar dan mentaati aturan

\section{Daftar Pustaka}

Bungin, Burhan.2003. Analisis Data Penelitian Kualitatif, PT.Raja Grafindo

Persada, Jakarta

Ching, DK.1991. Arsitektur, Bentuk Ruang dan Susunannya, Erlangga Jakarta

Lang,Jon.1987.Creating Architectural Theory, Van Nostrand Reinhold, USA

Moleong, Lexy.J.1989. Metodologi Penelitian Kualitatif, PT.Remaja Rosdakarya, Bandung

Rapoport, Amos. 1995.House Form and Culture, University of Wisconsin, Milwaukee,

Schultz, Christian Norberg.1971.Existence, Space \& Architecture, Paeger Publisher, New York

Sommer, Robert, Sommer B, Barbara.1980. A Practical Guide to Behavioral Research, Clifford University Press

Tuan, Yi-Fu.1977. Space and Place, University of Minnesota Press, Minneapolis

Van de Ven, Cornelis.1995,Ruang dalam Arsitektur, PT.Gramedia Pustaka Utama, Jakarta 